\title{
Hambatan yang Ditemui Dalam Perwalian Anak di Bawah Umur Berdasarkan Surat Penetapan Pengadilan Negeri di Wilayah Hukum Pengadilan Negeri Padangsidimpuan
}

\author{
Sarmadan Pohan ${ }^{1}$ \\ ${ }^{1}$ Fakultas Hukum Universitas Muhammadiyah Tapanuli Selatan, Sumatera Utara \\ Email : sarmadan.pohan@um-tapsel.ac.id
}

\begin{abstract}
ABSTRAK
Tulisan ini bertujuan untuk Untuk mendapatkan gambaran tentang praktek perwalian yang merupakan salah satu upaya hukum untuk melindungi kepentingan seorang anak dibawah umur.Metode yang dipergunakan dalam menganalisa permasalahan penulis akan menggunakan metode penelitian secara deskriptif dengan cara Library Research dan Field Research dengan memakai teknik pengumpulan data dengan melalui interview dan studi dokumentasi, dan setelah data terkumpul akan diuji melalui teknik pengujian deduktif dan induktif. Kesimpulan dalam penelitian bahwa Kitab Undang-Undang Hukum perdata menentukan seseorang yang belum berumur 18 tahun adalah masih anak di bawah umur, akan tetapi berdasarkan perkembangan hukum dapat diletakkan dibawah perwalian adalah orang yang berumur dibawah 18 tahun saja. Dan Seorang anak yang tidak berada dibawah kekuasaan orangtua diletakkan dibawah perwalian apabila umurnya belum mencapai 18 tahun.
\end{abstract}

Kata-kata Kunci: Perwalian, Anak, Dibawah umur

\section{PENDAHULUAN}

Seorang wali adalah pemegang amanah yang kewajibannya untuk melaksanakan dan mempertanggungjawabkan kepentingan seseorang manusia yang masih dibawah umur, karena ruang lingkup perwalian yang diatur dalam undang-undang hokum perdata ternyata tidak saja menyangkut diri pribadi sianak, melainkan termasuk harta kekayaan sianak yang merupakan bekal hidup.

Dalam sistem hukum ditentukan adanya subyek hukum yang cakap berbuat untuk melangsungkan hubungan-hubungan hukun atau bertindak secara hukum, namun disamping itu diatur pula ada orang sebagai subyek hukum yang tidak cakap bertindak secara hukum atau tidak cakap melangsungkan hubungan hukum. Dan orang-orang yangdisebut sebagai orang yang tidak atau tidak mampu bertindak secara hukum adalah orang yang masih dibawah umur. Masalah perwalian atau yang disebut dengan istilah voogdij yang diatur 
dalam pasal 331 Kitab Undang-Undang Hukum Perdata (BW) termasuk didalamnya adalah anak yatim piatu atau anak-anak yang belum cukup umur dan tidak dalam kekuasaan orang tua memrlukan pemeliharaaandan pembimbingan.

Menurut Surbekti (1986:1998) Ketentuan hukum sebagai hak seperti dijelaskan diatur dalam Kitab Undang - Undang Hukum Perdata pada pasal 2 (ayat) 1 yang berbunyi bahwa “anak yang dalam kandungan seorang perempuan dianggap sebagai telah dilahirkan apabila kepentingan si anak yang menghendaki. Adapun yang tergolong anak di bawah umur atau anak yang belum dewasa ditentukan batasan usia belum 21 tahun dan tidak lebih dahulu telah kawin, yang mana secara hukum orang seperti ini digolongkan sebagai anak yang tidak cakap bertindak (handelingsonbekwaan) dalam lalu lintas hukum yang oleh hukum mereka tentukan tidak dapat mengadakan hubungan - hubungan hukum, maka oleh sebab itu orangtua nya diwajibkan menyelenggarakan segala kebutuhannya di dalam hukum.

Adapun orang ketiga yang diatur dalam ketentuan hukum perdata yaitu sebagai orang yang berhak mengambil alih kekuasaan kedua orang tua si anak yang telah meninggal dunia disebut dengan istilah perwalian (Voogdij) sebagiamana diatur dalam pasal 331 Kitab Undang-Undang Hukum Perdata. Yang dimaksud sebagai wali adalah “orang atau perkumpulan-perkumpulan yang akan menyelenggarakan keperluan hidup anak-anak tersebut (Kansil, 1980:203).

Dalam berbagai pendapat para ahli hukum perdata khususnya bidang hukum kekeluargaan menyatakan yang dimaksud dengan perwalian terdapat beberapa pengertian antara lain menurut R. Subekti, menyatakan bahwa perwalian adalah, "pengawasan terhadap si anak yang masih di bawah umur, yang tidak berada dibawah kekuasaan orang tua serta pengurusan benda atau kekayaan anak tesebut diatur oleh undang - undang (Subekti, 1985:52).

Sebagai pihak yang menerima perwalian atau yang disebut dengan seorang wali adalah orang atau perkumpulan-perkumpulan yang akan menyelenggarakan keperluan-keperluan hidup anak-anak tersebut.Sehubungan dengan masalah perwalian ini, apabila diperhatikan ketentuan hukumnya bertujuan untuk melakukan kepentingan orang lain menurut hukum belum mampu berbuat secara hukum, dimanan kekuasaan wali dalam perwalian ini diselenggarakan tidak saja terhadap diri pribadi si anak melainkan juga mencakup harta kekayaan milik anak tersebut. Maka dengan memperhatikan sasaran atau obyek perwalian tersebut diatas jelas sangat luas hukum membarikan tenggung jawab terhadap seorang wali, karenanya dengan alasan tersebut penulis tertarik untuk menentukan topik ini sebagai obyek yang diteliti. 


\section{PEMBAHASAN}

Dengan melalui berbagai penjelasan pada uraian terdahulu maka seterusnya akan dilakukan analisa data terhadap praktek perwalian yang berkembang ditengah-tengah masyarakat dan bagaimana dijelaskan dalam uraian teoritis tentang perwalian ini dalam hukum dikenal tiga bentuk perwalian. Salah satu bentuk perwalian yang dimaksudkan adalah adanya ketentuan udnang-undang yang menentukan bahwa apabila suami atau istri meninggal dunia maka oleh pihak yang masih hidup akan menjadi wali atas anak-anaknya yang masih dibawah umur. Kenyataan dalam perkembangan masyarakat ternyata bentuk perwalian seperti masih tetap dipertahankan.

Maka dengan demikian berarti perwalian suami atau istri adalah merupakan bentuk perwalian yang terjadi dengan tanpa terlebih dahulu menunggu adaya suatu perbuatan hukum untuk melahirkan suatu perwalian. Kelainkan berdasarkan keyakinan yang berkembang dan terus diikuti masyarakat adalah otomatis perwalian tersebut berada dibawah kendali orang tua yang masih hidup.

Namun dengan ketentuan perundang-undangan tentang masalah perwalian suami atau istri ini apabila dikaitkan dengan kenyataan jelas perwalian ini masih tetap dikuatkan dengan surat perjanjian dan tidak jarnag mendapat penetapan dari hakim sebagai suatu persyaratan untuk syahnya perwalian.

Maka dengan demikian jika misalnya yang meninggal dunia adalah suami maka kewajiban bagi si istri mengajukan permohonan kepada pengadilan negeri supaya ditetapkan secara hokum bahwa anak - anaknya yang usianya masih dibawah umur berada perwaliannya. Sehingga inilah yang menjadi salah satu bukti bahsa perwalian dalam kehidupan masyarakat masih tetap sebagai salah satu alternatif dalam pemeliharaan anak-anak yang tinggal mati orangtuanya.

Dalam hubungannya dengan bentuk perwalian atas dasar penunjukan adalah merupakan kemungkinan kepada pihak suami atau istri untuk mengangkat seseorang wali bagi anakanaknya dan dalam kenyataaan yang terjadi pada prakteknya ketentuan perwalian seperti dilakukan dengan perbuatan suatu surat wasiat. Yang isinya biasanya menyangkut tentang cara-cara pemeliharaan seorang anak dibahwa perwalian serta berisi pula mengenai keberadaan harta warisan serta kapan hak sianak dapat dipergunakan atau dilepas dari pengawasan si wali serta lain-lain ketentuan yang kemungkinan bisa dilakukan si wali demi kepentingan sianak yang ditaruh dibawah perwaliannya. 
Dengan penjelasan tersebut diatas jelas bahwa bentuk perwalian dengan cara penunjukan ini dilakukan lewat surat wasiat, sehingga sudah barang tentu bentuk perwalian ini berlaku syah setelah kedua orang tua anak meninggal dunia. Dalam hubungannya dengan ketentuan perwalian yang dilakukan dalam sengketa kasus yang terdapat dalam studi kasus bahwa pelaksanaan perwalian tersebut dilakukan dengan cara waktu tergugat Rahuddin masih kecil dimana perwalian ini justru dilakukan ibunya setelah ayahnya meningal dunia dan ibunya sekalipun masih hidup merasa tidak ada kemampuan untuk mengawasi si anak sehingga demi kelanjutan hidup si anak oleh ibunya dilakukan perwlaian kepada pihak ketiga.

Maka sehubungan dengan itulah jelas bentuk yang berkembang ditengah-tengah masyarakat perwalian itu bisa dilakukan sekalipun salah satu orang tuanya masih hidup.Bahkan perwalian tersebut diserahkan terhadap pihak ketiga yang sebenarnya tidak mempunyai ikatan. Namun sekalipun demikian berdasarkan ketentuan yang terjadinya dipengadilan negeri Padangsidimpuan bahwa bentuk perwalian dengan cara penunjukan oleh hakim ini tidak berlaku atas dasar terjadinya perceraian antara suami atau istrinya. Hal ini jelas karena sesuai dengan ketentuan hukum perwalian sekalipun kedua orang tua bercerai kekuasaan dan pengawasan anak-anak dibawah umur tidak terputus karenanya.

Didalam hal putusnya kekuasaan orangtua terhadap si anak dibawah umur karena perceraian secara hukum otomatis menjadi tanggung jawab suami atau istri karena itu supaya tidak terjadi penyalahgunaan wali ini kiranya hakim benar - benar jeli untuk mempertimbangkannya. Sehubungan dengan itulah jelas bentuk perwalian ini inisiatif terdapat pada hakim untuk menentukan apakah dengan cerainya suami atau istri anak-anak dibawha umur perwalian. Dengan adanya kebebasan seperti diuraikan diatas menurut hemat penulis bahwa bentuk perwalian dengan cara penunjukan masih jarang dilakukan.

Dengan penjelasan diatas menggambarakan tentang maksud diaturnya bentuk perwalian dengan cara penunjukan dalam perundang-undangan tidak lain untuk memberikan kebebasan jika seseorang orangtua ingin melaksanakan perwalian. Sehubungan dengan itulan kiranya perwalian ini pada umumnya diperuntukkan bagi orang tua yang menghendaki pengaturan perwalian anak-anaknya sesudah ia tidak menjadi wali karena sebab kematian sebab dengan adanya penunjukan wali berdasarkan wasiat terhadap anak dibawah umur akan lebih terjamin khususnya kelangsungan hidup dan pendidikannya.

Adapun alasan penulis menyatakan demikian karena pada umumnya orangtualah yang lebih banyak mengetahui siapa orang yang akan dapat memberikan pendidikan maupun pemeliharaan anak-anaknya. Sebagai bentuk perwalian terakhir yang diatur dalam undangundang adalah bentuk perwalian dengan cara penetapan hakim. Dimana hal ini dimaksudkan 
agar perwlaian selain berkekuatan hukum juga akan mempunyai siatu sanksi jika siwalinya melakukan kesalahan maupun kelalaian unutk membimbing sianak yang ditaruh dibawah pengawasannya.

Berdasarkan seluruh penjelasan tersebut diatas maka anak yang tidak berada dibawah kekuasaan orangtua tetapi berada dibawah perwalian terdapat perbedaan atau ketidakselarasan dikatakan demikian karena hubungan yang ada antara seorang anak dengan walinya adalah tergolong hubungan hukum seperti halnya suatu perjanjian. Maka dalam kaitan itu anak yang ditaruh dibawah perwalian yharus mamatuihi segala apa yang telah diperjanjikan didalam surat penetapan wali, demikian sebaliknya orang yang memegang amanah sebagai wali harus benar-benar mampu memelihara sianak sampai dengan batas usia yang diperjanjikan.

Dengan alasan tersebut diatas maka dapat disimpulkan bahwa perwalian dengan berbagai bentuk sebagaimana adanya dijelaskan diatas tidak sepenuhnya diikuti dalam praktek, melainkan pelaksanaan yang terjadi ditengah-tengah masyarakat lebih mengarah kepada ketentuan-ketentuan yang bersifat adat atau dengan kata lain kaitan hubungan keluarga atau sedarah masih merupakan persyaratan utama.

\section{Hak Dan Kewajiban Dalam Perwalian}

Sehubungan dengan pengertian perwalian adalah merupakan kewajiban hukum untuk memelihara dan mendidik anak dibawah umur yang tidak berada dalam kekuasaaan orang tuanya.Berarti perwalian sudah jelas adalah melahirkan hak dan kewajiban pada anak dengan walinya dari sudut ketentuan perundang-undangan yang berlaku adalah sudah cukup jelas tentang pengaturan hak dan kewajiban seorang wali terhadap anak dibawah umur. Dimana tidak lain adlah menyelenggarakan segala kepentingan sianak yang berada dibawah perwaliannya.Yang mana perwalian itu berarti lain adalah bertujuan untuk mengurus segala kepentingan si anak selama ia berada dalam perwalian.

Adapun kewajiban hukum yang terjadi tugas dan tenggung jawab seorang wali adalah meliputi pribadi si anak dan sekaligus harta kekayaannya justru karena itulah pada prinsipnya hak dan kewajiban seorang wali itu adalah sama dengan hak dan kewajiban oleh orang tua kepada anaknya.Dan menurut analisa penulis tentang keberadaan hak dan kewajiban anak dengan wilayah dapatlah dinyatakan sebagaimana hak dan kewajiban si anak dengan orangtuanya dimana dilaksanakan adalah atas karena perintah undang-undang sehingga hak dan kewajiban itu adalah berlaku demi hukum pada saat mulai perwalian itu berlaku. 
Demikian juga kewajiban seorang wali untuk memelihara dan mendidik anak yang berada dalam perwaliannya kiranya pembatasan yang diberikan oleh perundang - undangan menurut hemat penulis adalah sudah cukup tepat, dimana seorang wali tidaklah diwajibkan untuk memberikan pemeliharaan dan pendidikan itu terhadap si anak diluar batas kemampuan harta kekayaan yang dimiliki anak tersebut.

Sehubungan dengan kewajiban untuk memelihara dan mendidik ini maka menurut analisa penulis seorang wali harus mengurus tempat tinggalnya pendidikannya, kehidupan masa depannya perkawinannya dan termasuk memberi nafkah apabila tidak ada lagi yang memberi biaya. Apabila diperhatikan kewajiban seorang wali seperti disebutkan diatas berarti dapat dianalisa kewajiban itu adalah benar-benar merupakan suatu keadaan yang sangat berat sehingga didalam pelaksanaan nya memerlukan pengorbanan dan keikhlasan.Sebab dengan tanpa melalui ini penulis berkeyakinan kewajiban sedemikian tidak mungkin terlaksana.

Demikian uga dalam kaitannya dengan kewajiban siwali terhadap pribadi anak dibawah umurakan semakin sulit untuk dipenuhi apabila yang mengaku perwalian itu adalah bukan salah satu dari kedua orang tuanya, sehingga menurut analisa penulis demi terwujudnya pelaksanaan kewaiban seorang wali unutk hendaknyalah perwalian itu diletakkan pada salah satu orang tua sianak. Jika demikian sekalipun didalam perundang-undangan perwalian itu dapat diletakkan pada setiap orang akan tetapi sehubungan dengan tugas dan tenggung jawab adalah sedemikian beratnya maka apabila perwalian itu tidak mungkin diletakkan pada salah satu orang tua anak, sudah sepatutnya apabila wali tersebut adalah orang yang memiliki sifat jujur dan adil. Sebab wali yang sedemikianlah yang mungkin dapat melaksanakan kewajibannya dalam rangka untuk kepentingan pribadi si anak.

Kemudian jika penulis menganalisa dari sudut lain kiranya dapat seorang wali untuk memanfaatkan harta kekayaan si anak untuk melaksanakan kewajibannya itu demi tegaknya kepentingan pribadi si anak sebagaimana yang diharapkan oleh perundang-undangan. Dalam memanfaatkan harta kekayaan si anak dibawah umur, perundang-undangan memberikan pembatasan kepada seorang wali, sehingga terhadap benda-benda tetap tidaklah boleh dipindah tangankan ataupun diagunkan sekalipun hal itu untuk kepentingan si anak.

Menurut analisa penulis pembatasan-pembatasan simaksudkan adalah untuk menghindari sampai siwali tersebut leluasa terhadap harta kekayaan sianak akan tetapi dari hasil penelitian penulis dilapangan ternyata masih sering ditemukan dlam hal pemanfaatan harta kekayaan sianak wlai tidak mengindahkan ketentuan perundang-undangan dimana apabila kepentingan anak benar-benar menghendaki penjualan ataupun mengandaikan barang tetap kekayaan sianak tanpa ada kuasa dari pengadilan. 
Sebenarnya tindakan yang dilakukan wali dalam melakukan perwalian menjual atau mengandaikan barnag-barang tidak bergerak yang menjadi kekayaan anak adalah merupakan pelanggaran terhadap kekuasaan yang diberikan oleh perundang-undangan kepada seorang wali, sebab perbuatan itu adalah dimungkinkan untuk dilakukannya apabila ada kuasa dari pengadilan negeri. Akan tetapi karena kenyataaan telah menunjukkan lain sebagaimana yang digariskan perundang-undangan maka menurut analisa penulis kekuasaan seorang wali untuk mengurus harta kekayaan anak telah menunjukkan adanya perkembangan hukum diwilayah hukum pengadilan negeri.

Sehubungan dengan penjelasan diatas, pelanggaran terhadap hak seorang wali dalam melaksanakan kewajibannya untuk mengurus kekayaan anak dalam praktek menunjukkan hal ini benar-benar tidak menimbulkan permasalahan sehingga tidak pernah ditemukam adanya tuntutan ganti rugi yang dimajukan kepada seorang wali dalam kaitannya dengan kewajiban untuk mengurus kekayaan anak yang berada dibawah perwalian. Dengan melalui penjelasan terhadap keberadaan hak dan kewaiban wali dalam melaksanakan perwalian terhdapa anak dibawah umur, maka apabila dianalisa dari kewajiban anak tersebut terhadap walinya undang-undang hanya menyebutkan menghormati dan mentaati kehendak walinya.

Konsep perundang-undangan dalam mengatur kewajiban anak dibawah umur terhadap walinya menurut analisa penulis adalah benar-benar menunjukkan demi kepentingan sianak, sehingga tidak ada kewaiban hukum yang dapat diperoleh wali dari padanya selain memberikan penghormatan dan mengikuti kehendaknya. Demikian dengan seorang anak yang berada dibawah perwalian tidaklah dapat dipaksakan walinya supaya memenuhi semua kemauan dengan tanpa ada pembatasan, sebab anak dibawah umur yang tidak mau mematuhi perintah walinya karena alasan perintah itu adalah merupakan suatu hak yang tidak baik menurut pandangan masyarakat umum tidak dapat dikatakan sianak telah melalaikan kewajibannya.

Jadi perkataan kewajiban untuk mengikuti kemauan wali dimaksudkan disini harus ditafsirkan dalam pengertian yang lebih sempit sehingga perintah wali. Terhadap anak untuk membunuh atau mencuri nya, tidaklah diwajibkan kepada anak untuk mengikutinya.Sebab perintah membunuh atau mencuri itu adalah merupakan perbuatan yang dilarang undang undang dan masyarakat pada umumnya.

Berdasarkan seluruh uraian tersebut di atas jelas persoalan perwalian hanya ditujukan terhadap masa depan dan pendidikan si anak selama dalam masa pengawasan atau perawatan walinya. Karena itu perbuatan baik sebagai tindakan dalam pergaulan si anak adalah 
merupakan sesuatu keharusan yang akan di ajarkan oleh wali terhadap anak yang dibawah perwaliannya.

Kedalam persoalan masalah - masalah yang berkaitan dengan hubungan atau ikatan darah sianak selama dalam perawatan walinya harus terus ditegakkan oleh walinya .Dengan kata lain seperti ditegaskan hakim bahwa seorang wali anak dibawah umur tidak boleh mengajatkan sikap sianak untuk menjauh dari hubungan famili baik dari ayahnya maupun ibunya, maupun dengan saudara-saudaranya yang lain dan bahkan waib bagi wali untuk memperkenalkannya hanya terhadap anak yang berada dibawah perwaliannya

\section{PENUTUP}

Sekalipun kitab undang-undang hukum perdata menentukan seseorang yang berumur 18 tahun adalah masih anak dibawah umur akan tetapi berdasarkan perkambangan hukum dewasa ini yang dapat diletakkan dibawah perwalian adalah orang yang berumur dibawha 18 tahun saja.Seorang anak yang tidak berada dibawah kekuasaan orangtua diletakkan dibawah perwalian apabila umurnya belum mencapai 18 tahun.

\section{DAFTAR PUSTAKA}

Abdul Kadir Muhammad, Hukum Perdata Indonesia, Citra Adtya Bakti, Bandung, 1990 A.Safioedin, Hukum Orang dan Keluarga, Alumni Bandung, 1986

H. Riduan Syahrani. Seluk Beluk dan Asas-Asas Hukum Perdata.Bandung: Alumni. 2004

H. Zainuddin Ali. Filsafat Hukum. Jakarta: Sinar Grafika, 2006

Jeremias Lemek. Mencari Keadilan .Yogyakarta: Galang Press, 2007

Kansil, Pengantar Ilmu Hukum dan Tata Hukum Indonesia, Balai Pustaka, Jakarta, 1980

Khudzaifah Dimyati. Teorisasi Hukum. Surakarta: Muhammadiyah Press.2004

Departemen Kehakiman. RI, Bahan Pokok Penyuluhan Hukum Bidang Perdata, Jakarta, 1986

Departemen Agama.RI,Al-qur’an dan Terjemahan, Jakarta, 1986

Kartini Kartono, Pengantar Methodologi Research, LP3ES, Jakarta, 1986

R. Sortojo Prawirohamidjojo, Hukum Keluarga, Rajawali, Jakarta, 1998

R. Subekti dan R. Tjitrosidibio, Kitab Undang-Undang Hukum Perdata, Pradnya Paramita , Jakarta, 1986 
Retno Wulan Sutantion. Hukum Acara Perdata.Bandung: Mandar Maju. 2005

R. Subekti, Pokok-Pokok Hukum Perdata, Pradnya Paramita, Jakarta, 1988

Satjipto Raharjo. Hukum di Indonesia.Jakarta: PT Kompas Media Nusantara. 2006

Sumadi Surayabrata, Methodelogi Penelitian, Rajawali, Jakarta, 1983

Sri Harini Dwiyatmi. Pengantar Hukum Indonesia.Bogor: Ghalia Indonesia. 2006 